\title{
Performance evaluation of a developed rice-processing machine
}

\author{
Adisa A. Folami, ${ }^{1}$ Eberendu N. Obioha, ${ }^{1}$ Aderinlewo A. Adewole, ${ }^{1}$ Kuye S. Ibiyemi ${ }^{2}$ \\ ${ }^{1}$ Department of Agricultural Engineering; and ${ }^{2}$ Department of Mechanical Engineering, Federal \\ University of Agriculture, Abeokuta, Nigeria
}

\begin{abstract}
Rice processing machines produced in developed countries are mostly unaffordable by rural farmers, hence there was need to develop cost effective/efficient machines produced from available local materials desirable in food industry that meets the need of the rural farmers. This study was to evaluate the performance of a developed rice dehusking/destoning machine at Federal University of Agriculture, Abeokuta, Nigeria. Minitab 16 was used for analysis of variance of two main factors [four paddy varieties Faro 35, Faro 44, Faro 55 and Ofada and five moisture content (MC) groups] to obtain its optimum operational parameters. Cleaning efficiency, coefficient of dehulling, coefficient of wholeness, dehulling efficiency, dehulling recovery and output capacity were optimum at $94.60 \%, 0.63,0.85,50.54 \%, 61.22 \%$ and 18.53 $\mathrm{kg} / \mathrm{h}$ respectively. The effect of MC and test paddy variety on coefficient of wholeness and dehulling efficiency were significant while only MC effect was significant at $\mathrm{P}<0.05$ on cleaning efficiency. Paddy varieties had effect on rice quality, long and slender grains had more breakage than shorter grains. After further work of improvement, its coefficient of dehulling, dehulling efficiency and dehulling recovery were $0.82,65$ and $75 \%$ respectively.
\end{abstract}

\section{Introduction}

Rice (Oryza sativa L.) is a staple food consumed by over half the

Correspondence: Adisa Alex Folami, Department of Agricultural Engineering, Federal University of Agriculture, Abeokuta, Nigeria. Tel: +2348036318696 .

E-mail: alexadisa@yahoo.co.uk

Key words: Dehulling; efficiency; Teflon; test paddy.

Conflict of interest: the authors declare no potential conflict of interest.

Received for publication: 18 August 2015.

Accepted for publication: 7 January 2016.

(C) Copyright A.A. Folami et al., 2016

Licensee PAGEPress, Italy

Journal of Agricultural Engineering 2016; XLVII:506

doi:10.4081/jae.2016.506

This article is distributed under the terms of the Creative Commons Attribution Noncommercial License (by-nc 4.0) which permits any noncommercial use, distribution, and reproduction in any medium, provided the original author(s) and source are credited. world population. Nigeria consumed about 5.9 million metric tons of milled rice, and local production amounted to about 4.5 million metric tons of paddy rice in year 2012 while 2.7 million metric tons of milled rice was imported. Local rice production faces competition from imported rice, which is favoured for its long white clean grains stones free but taste less than the local varieties. Eliminating stones from Nigerian rice, by using a destoner/huller with locally available materials at low cost when compared with expensive imported ones, would allow Nigerian locally produce rice to be appreciated better than imported rice. Raising the quality of local rice might discourage rice importation, whilst boosting local production.

Ogunfowora (2007) reported poor mastery of parboiling and milling techniques as part of major factor exacerbating rice quality problems, resulting in low market price, which in turn led to very low returns to rice processing activities. It was clear from his study that the major challenge to improve rice quality was the development of low cost but technically efficient and cost effective parboiling and milling technologies. Careful drying after harvest, threshing and parboiling is essential to prevent mould formation, discoloration and fermentation of the rice paddy. The milling stage is the point where actual dehulling (or dehusking) occurs. Dehusking is the removal of husk or hull. The rice milling operation is the separation of the husk (dehusking) and the bran (polishing) to produce the edible portion (endosperm) for consumption (Mejia, 2003). There are mainly three methods of rice dehulling (or dehusking) in Nigeria. These are traditional or handpounding method, the small-mill processing method and the large-mill processing method (Adewunmi et al., 2007).

Design and development of roller dehusking prototype machine have been carried out by some researchers with gradual improvements. Lewis in Silsoe College, Bedford, England, initiated the work on rubber roller rice dehusking machine prototype development, and this was found to be fairly satisfactory but required 64 watts power for dehusking $13 \mathrm{~kg}$ of paddy with a high wear rate of rubber roller at 0.94 mm (Lewis L.0., unpublished thesis, 1979). Rasaq worked further on the same machine and attained 81.4 watts power for dehusking 64 $\mathrm{kg} / \mathrm{h}$ of paddy with a reduced wear rate of rubber roller at $0.019 \mathrm{~mm}$ (Rasaq I.M., M.Sc. unpublished thesis, 1981). Adisa in 1987 and 1991 researched on the assessment of power demand of same machine to further reduce the power requirement, and search for suitable locally available material for roller and alternative source of power supply in England and in Nigeria (Adisa A.F., unpublished M.Sc., 1987).

In March 2010 a team of researchers at the Federal University of Agriculture, Abeokuta (FUNAAB) in Ogun State, Nigeria commenced rice dehusking/destoning machine development project at the Institute of Food Security, Environmental Resources and Agricultural Research for use in rural areas where most of the country's production comes from. This study was a performance evaluation of this machine using Teflon rollers, which was the next major research work in search of suitable local materials desirable for food industry carried out by these sets of researchers. 


\section{Materials and methods}

This study was conducted on roller machine at the Central Engineering Workshop of the FUNAAB, Abeokuta, Ogun State, Nigeria. About $2.8 \mathrm{~kg}$ each of Faro 35, 44, 55 and Ofada varieties were obtained for the performance evaluation of the locally developed rice dehusking/destoning (Figure 1).

The chemical properties of Teflon, molecular bonding, regular arrangement of flourines around the carbon atoms and ability to retain its properties at high temperature as high as $240^{\circ} \mathrm{C}$, makes it desirable material in food and chemical industry where it does not corrode or react with anything when in use (Hwang et al., 2005).

The rollers of the prototype rice dehuller/destoner were made of knolled Teflon rollers with $14.74 \mathrm{~cm}$ outer diameter moving at 995.5 rpm for fixed roller while adjustable roller moves at $725 \mathrm{rpm}$. The adjustable slow roller speed was at a speed of about $27 \%$ less than the fixed fast roller. Firouzi et al. (2010) reported that the adjustable roller normally runs at about $30 \%$ slower than the fixed one to create shearing effect. PNS/PAES (2004) reported that the rollers are driven mechanically and rotate in opposite directions, the adjustable one rolls normally at about $25 \%$ slower than the fixed one, thus $27 \%$ slow speed of adjustable roller of this prototype dehuller was close to average speed as suggested in past studies. The speed was measured by Tachometer (Lutron DT-2234B; Lutron Electronic Enterprise C0., Ltd., Taipei, Taiwan; phototype $0.1 \mathrm{rpm}-5 \approx 999.9 \mathrm{rpm} ; 1 \mathrm{rpm}-1000 \approx 99.999 \mathrm{rpm}$ ).

About $2.8 \mathrm{~kg}$ each from raw paddy rice samples were soaked in plastic containers and covered at a level just above the paddy, drained with sieve and then steamed for about 30 min, during which paddy kernels were split from top to bottom. Paddy rice samples were soaked in hot water at $80^{\circ} \mathrm{C}$ for $3 \mathrm{~h}$, as used by Ituen and Ukpaka (2011). The steaming (at boiling point) was done for $25-30 \mathrm{~min}$, the samples were taken out and allowed to temper for $3 \mathrm{~h}$ (aiming at reducing the moisture content to prevent cracking while drying) as suggested by Dauda et al. (2012). The samples were sun dried for about $3 \mathrm{~h}$, being the rainy season and shade dried for 1-4 days, by spreading paddy thinly on matted bags and stored in airtight bags and plastic containers before dehulling.

Moisture content was determined using the Air-0ven method using electric oven dryer (General-Model $5222 \mathrm{NE}, 230 \mathrm{~V}$ ). The weighing was done by weighing scale with Amput electronic scale (sensitivity $0.01 \mathrm{~g}$ ).

Physical dimensions (length, breadth and thickness) of paddy and grain were determined by randomly picking twenty whole grains, measured by means of vernier callipers and magnifying lens. The mean of these dimensions was then calculated in accordance with NCRI and WARDA (2007) as shown below:

Length to width ratio (L/W) = Average paddy length, $\mathrm{mm}$

(1)

$$
\text { Average paddy width, } \mathrm{mm}
$$

\section{Results and discussion}

Fed into the prototype huller were $500 \mathrm{~g}$ each of four varieties of paddy, under this study, at different moisture content groups. Three replicates of $100 \mathrm{~g}$ rough rice samples (sub samples) were each taken from samples to determine the following variables (PNS/PAES, 2004; Dauda et al., 2012) as summarised in Table 1. Grain lengths and widths gave their shapes as shown respectively hence classified both as medium grains. Faro 44 grains shape was classified as long grain with a slender shape, while Ofada grains was classified as short grain based on the standards of IRRI (1996).
Cleaning of paddy-related to dockage (Table 2) involves the separation of undesirable foreign matter or materials other than grain and leaving a cleaned paddy by the aerodynamic mechanism. The average terminal velocity of dehusked rice grain was $7.5 \mathrm{~m} / \mathrm{s}$ while the set blower air velocity was $9.8 \mathrm{~m} / \mathrm{s}$. The maximum cleaning efficiency and minimum were as shown in Table 3 . Although researchers suggested that paddy should undergo cleaning at pre milling stage in order to have high quality rice (Mejia, 2003), this paddy was neither skimmed nor cleaned so that the cleaning efficiency of the dehuller could be determined. It was observed that the husk outlet had negligible amount of whole grains, broken rice, and unhulled paddy blown away with the chaff.

The effect of paddy moisture content on rice breakage is shown in Figure 2. It was likely due to the level of moisture content (MC) in some grains, which gave some kind of resistance to breakage because Dilday (1987) reported that rice breakage during the milling process decreased with the increasing paddy moisture content as shown in Tables 2 and 4 . Ofada had less breakage at $1.78 \mathrm{~mm}$ roller gap than at $1.5 \mathrm{~mm}$ gap thus agreeing with Matthews et al. (1970) who reported that rice breakage was mostly due to mechanical stresses rather than
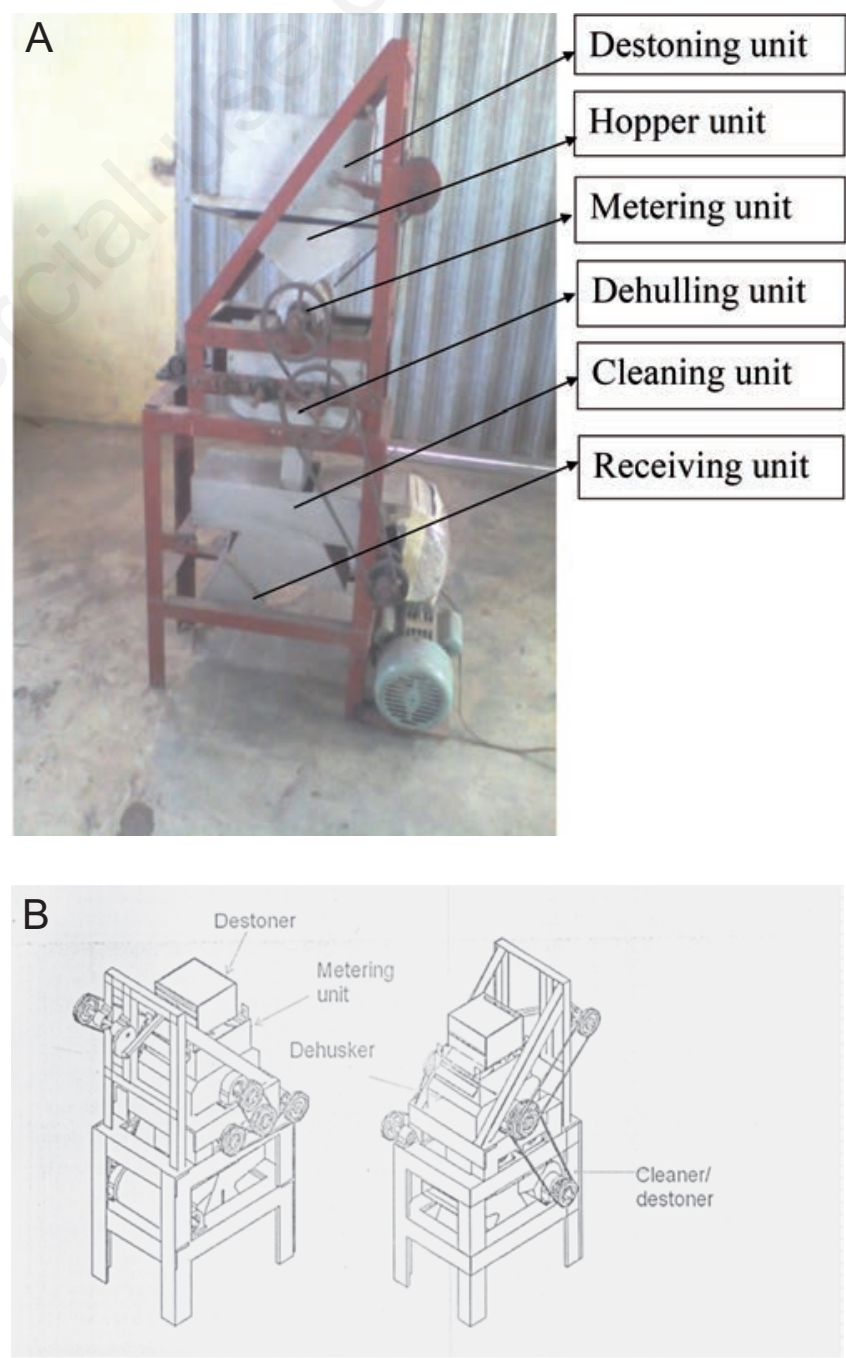

Figure 1. A) Prototype rice dehusking/destoning machine; B) isometric views of prototype rice dehusking/destoning machine. 
thermal stresses. The least dimension for Ofada was $1.59 \mathrm{~mm}$ (Table 4) thus lesser roller spacing would yield more breakage and in turn less head rice.

The highest percentage of whole rice, at a single pass and huller maximum coefficient of wholeness, were as shown in Table 2. This may be due to the fact that long grains are more susceptible to breakage during milling (Goodman and Rao, 1985). Dilday (1987) reported that rice breakage during the milling process decreased with the increasing paddy moisture content as observed in Faro 35 (Table 5). Coefficient of wholeness was maximum for Ofada, Faro 55, Faro 35 and Faro 44, as shown in Table 2.

Faro 35, Faro 55 (both medium grains) and Ofada and Faro 44 had maximum dehulling recovery as shown in Table 3. At 12.00-13.99\% MC and $1.5 \mathrm{~mm}$ roller clearance for all Faro varieties, Faro 44 had the least dehulling recovery; this was significant and may be due to its paddy grains having the least width of $2.20 \mathrm{~mm}$ compared to the other Faro varieties (Table 4). The dehulling recovery significantly increased and then decreased after reaching $16.00-17.99 \%$ MC. It was likely that an increase in MC led to an increase in paddy width such that there was greater friction for dehulling. The above results agrees with IRRI (2009a, 2009b) that the maximum milling recovery is $69-70 \%$ depending on rice variety, but because of grain imperfections and the presence of unfilled grains, commercial millers may achieve $65 \%$ milling recovery, however some village type rice mills have $55 \%$ or lower

Table 1. Determination of variables.

\begin{tabular}{|c|c|c|}
\hline Variables & Formulae & Parameters \\
\hline 1. Dockage (purity) & (Weight of dockage/total weight of sample) $\times 100$ & \\
\hline 2. Coefficient of dehulling & $\mathrm{e}_{\mathrm{h}}=1-\frac{\mathrm{W}_{\mathrm{u}}}{\mathrm{W}_{\mathrm{s}}}$ & $\begin{array}{l}\mathrm{e}_{\mathrm{h}}=\text { coefficient of dehulling } \\
\mathrm{W}_{\mathrm{u}}=\text { weight of unhulled paddy, } \mathrm{g} \\
\mathrm{W}_{\mathrm{s}}=\text { weight of paddy sample (mixture of brown rice and } \\
\text { unhulled paddy), } \mathrm{g}\end{array}$ \\
\hline 3. Coefficient of wholeness & $\mathrm{e}_{\mathrm{W}}=\frac{\mathrm{W}_{\mathrm{w}}}{\mathrm{W}_{\mathrm{T}}}$ & $\begin{array}{l}\mathrm{e}_{\mathrm{W}}=\text { coefficient of wholeness } \\
\mathrm{W}_{\mathrm{w}}=\text { weight of whole brown rice in the sample, } \mathrm{g} \\
\mathrm{W}_{\mathrm{T}}=\text { weight of the total brown rice hulled (whole and broken), g }\end{array}$ \\
\hline 4. Broken rice & Broken rice $(\%)=\frac{W_{\mathrm{b}}}{\mathrm{W}_{\mathrm{T}}} \times 100$ & $\begin{array}{l}\mathrm{W}_{\mathrm{b}}=\text { weight of broken brown rice in the sample, } \mathrm{g} \\
\mathrm{W}_{\mathrm{T}}=\text { total weight of brown rice dehulled (whole and broken), } \mathrm{g}\end{array}$ \\
\hline 5. Head rice & Head rice $(\%)=\frac{W_{w}}{W_{T}} \times 100$ & Same as above \\
\hline 6. Dehulling efficiency & $\mathrm{E}_{\mathrm{h}}=\mathrm{e}_{\mathrm{h}} \mathrm{e}_{\mathrm{w}} \times 100$ & $\begin{array}{l}\mathrm{E}_{\mathrm{h}}=\text { dehulling efficiency, } \% \\
\mathrm{e}_{\mathrm{h}}=\text { coefficient of dehulling } \\
\mathrm{e}_{\mathrm{w}}=\text { coefficient of wholeness }\end{array}$ \\
\hline $\begin{array}{l}\text { 7. Potential milling/ } \\
\text { dehulling recovery (DR) }\end{array}$ & Potential DR $(\%)=\frac{W_{T}}{W_{c}} \times 100$ & $\mathrm{~W}_{\mathrm{c}}=$ weight of cleaned paddy sample, $\mathrm{g}$ \\
\hline 8. Dehulling capacity & $\mathrm{H}_{\mathrm{c}}=\frac{\mathrm{H}_{0} \mathrm{e}_{\mathrm{h}}}{\mathrm{T}_{0}}$ & $\begin{array}{l}\mathrm{H}_{\mathrm{c}}=\text { dehulling capacity, } \mathrm{kg} / \mathrm{h} \\
\mathrm{H}_{0}=\text { total huller output, } \mathrm{kg} \\
\mathrm{e}_{\mathrm{h}}=\text { dehulling coefficient } \\
\mathrm{T}_{0}=\text { operating time, } \mathrm{h}\end{array}$ \\
\hline 9. Output capacity & Output capacity $(\mathrm{kg} / \mathrm{h})=\frac{\mathrm{H}_{0}}{\mathrm{~T}_{0}}$ & Same as above \\
\hline $\begin{array}{l}\text { 10. Capacity } \\
\text { utilisation (CU) }\end{array}$ & $\mathrm{CU}=\frac{\text { Output capacity }}{\text { Input capacity }} 100(\%)$ & \\
\hline 11. Cleaning efficiency & Cleaning efficiency $=\frac{\mathrm{W}_{\mathrm{c}} \times 100}{\overline{\mathrm{W}}_{\mathrm{s}}}$ & $\begin{array}{l}\mathrm{W}_{\mathrm{c}}=\text { weight of clean rough rice sample, } \mathrm{g} \\
\mathrm{W}_{\mathrm{s}}=\text { weight of paddy sample (mixture of brown rice, unhulled paddy } \\
\text { and dockage), g }\end{array}$ \\
\hline
\end{tabular}

Table 2. Prototype dehuller effect on milling efficiency of rice varieties.

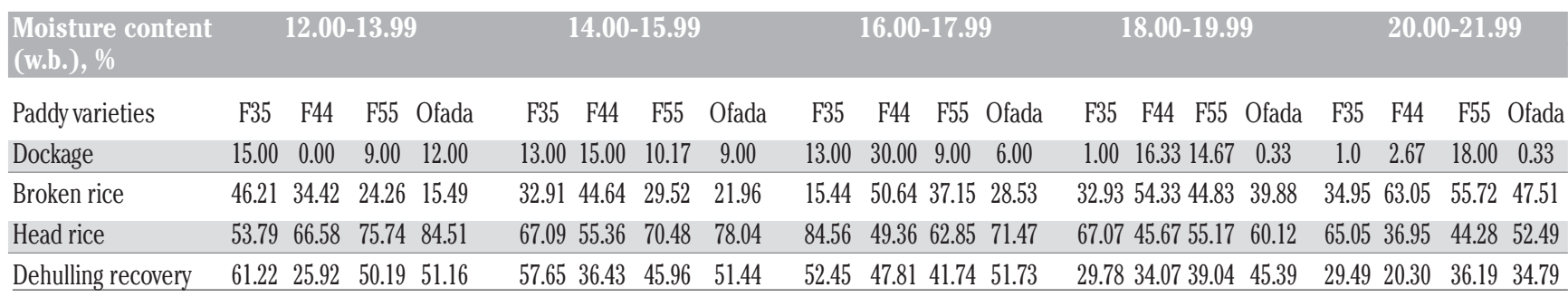

F35, Faro 35; F44, Faro 44; F55, Faro 55. 
milling recovery. From Tables 2 and 3, the dehuller maximum coefficient of dehulling was 0.63 for Faro 35 at 12.00-13.99\% MC. Above $16.00-17.99 \% \mathrm{MC}$, dehulling decreased due to MC higher cohesion of the hull to the brown rice for all varieties, it was possible that the adhesion of the paddy grains to the rollers was due to increased moisture content. This result agrees with that reported by Firouzi et al. (2010) under field conditions and Payman et al. (2006) under laboratory conditions.

Figure 2 shows Ofada, Faro 55, Faro 44 and Faro 35 maximum dehulling efficiency respectively at various MC groups. Also it shows Faro 35, Ofada, Faro 55 and Faro 44, the least dehulling efficiency respectively MC level. The huller maximum dehulling efficiency was $50.54 \%$ for Faro 35 at $16.00-17.99 \%$ MC, this may be due to increased
MC leading to increased width and better contact with rollers, and minimum dehulling efficiency of $11.25 \%$ for Faro 44 at 20 to $21.99 \%$ may be due to excess moisture resulting in stickiness. This was caused mainly by the varying thickness of the paddy grains.

Faro 35, Faro 44 and Ofada had maximum dehulling capacity of 7.37, 7.08 and $10.59 \mathrm{~kg} / \mathrm{h}$ respectively at $16.00-17.99 \%$ MC while Faro $55 \mathrm{had}$ optimal dehulling capacity of $6.38 \mathrm{~kg} / \mathrm{h}$ at $12.00-13.99 \% \mathrm{MC}$ range. The least overall dehulling capacity for all paddy varieties was at 20.00 $21.99 \%$ MC. Maximum dehulling capacity of the dehuller was $10.59 \mathrm{~kg} / \mathrm{h}$ at $16.00-17.99 \% \mathrm{MC}$ for Ofada (Figure 3). There was an increase in overall dehulling capacity for all paddy varieties as MC increased and then the dehulling capacity decreased after reaching $16.00-17.99 \% \mathrm{MC}$ level. The varying results were due to the timing of the rate of output

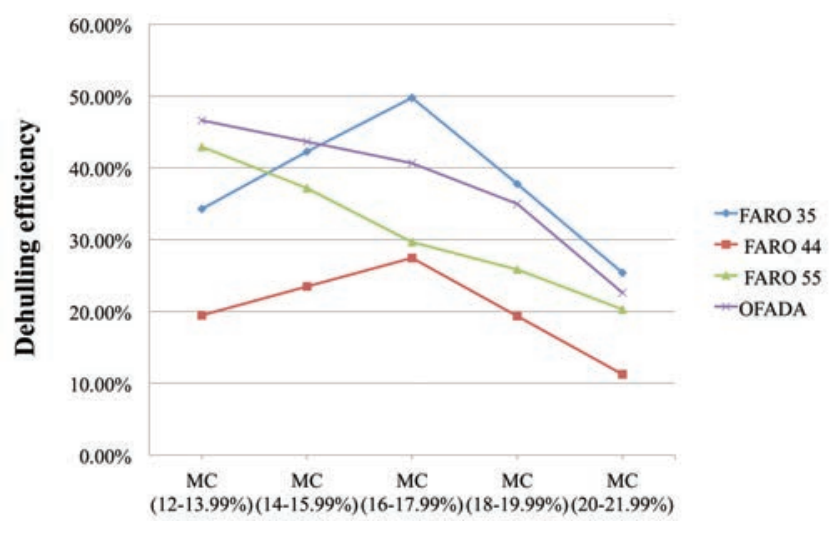

Figure 2. Effect of moisture content (MC) on dehulling efficiency.

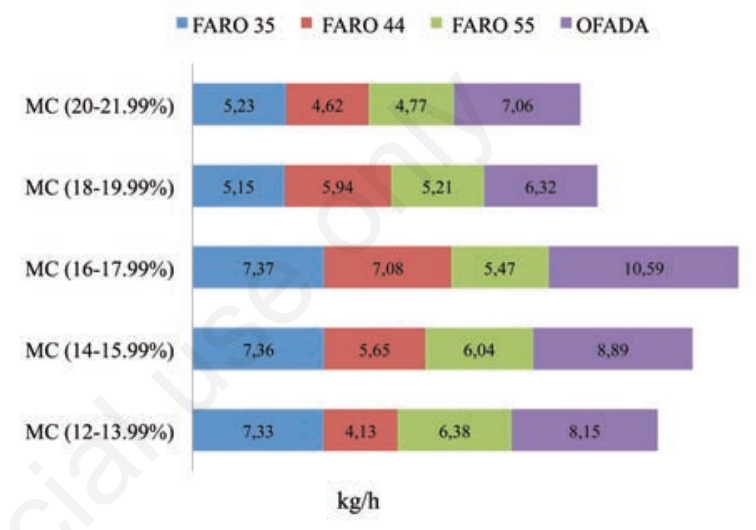

Figure 3. Effect of moisture content (MC) on dehulling capacity.

Table 3. Performance parameters of the dehuller on paddy varieties.

\begin{tabular}{|c|c|c|c|c|c|c|c|c|c|c|c|c|c|c|c|c|}
\hline \multirow{2}{*}{$\begin{array}{l}\text { Moisture content } \\
(\text { w.b.), \% } \\
\text { Paddy varieties }\end{array}$} & \multicolumn{4}{|c|}{$12.00-13.99$} & \multicolumn{4}{|c|}{$14.00-15.99$} & \multicolumn{2}{|r|}{$16.00-17.99$} & \multicolumn{3}{|c|}{$18.00-19.99$} & \multicolumn{3}{|c|}{$20.00-21.99$} \\
\hline & F35 & F44 & $\mathrm{F} 55$ & Ofada & F35 & F44 & $\mathrm{F} 55$ & Ofada & F35 & F44 F55 Ofada & F35 & F44 & F55 Ofada & F35 F44 & 55 & Ofada \\
\hline Operating time, min & 2.41 & 2.05 & 2.42 & 2.02 & 2.30 & 2.10 & 2.46 & 1.74 & 2.32 & $\begin{array}{lll}2.16 & 2.49 & 1.47\end{array}$ & 2.02 & 2.00 & $2.51 \quad 2.19$ & $2.01 \quad 1.85$ & .53 & 2.20 \\
\hline Coefficient of dehulling & 0.63 & 0.30 & 0.57 & 0.55 & 0.62 & 0.42 & 0.53 & 0.56 & 0.59 & $0.54 \quad 0.47 \quad 0.5$ & 0.39 & 0.42 & $0.47 \quad 0.52$ & $0.39 \quad 0.30$ & 0.46 & 0.43 \\
\hline Coefficient of wholeness & 0.54 & 0.67 & 0.75 & 0.84 & 0.70 & 0.58 & 0.70 & 0.78 & 0.85 & $\begin{array}{lll}0.50 & 0.63 & 0.72\end{array}$ & 0.67 & 0.44 & $0.54 \quad 0.60$ & $0.65 \quad 0.38$ & 0.44 & 0.53 \\
\hline Dehulling efficiency, \% & 34.14 & 19.99 & 42.69 & 46.56 & 43.05 & 24.61 & 36.80 & 43.7 & 50.54 & $27.1429 .65 \quad 40.7$ & 25.83 & 18.59 & $25.73 \quad 31.3$ & 25.4511 .49 & 20.39 & 22.58 \\
\hline overy & 61.22 & 25.92 & 50.19 & 51.16 & 57.65 & 36.43 & 45.96 & 51 & 52.45 & 47.81 & 29.78 & 34.07 & 39.0445 & 29.4920 .30 & 36.19 & 34.79 \\
\hline Cleaning efficiency, \% & 0 & 94.73 & 86.84 & 91.85 & 90.12 & 91.08 & 87.46 & 90 & 85.90 & 0.6689 .2 & 87.56 & 35 & 86.4087 & 86.4587 .26 & 84.72 & 7.59 \\
\hline Output capacity, kg/h & 11.58 & 13.84 & 11.25 & 14.77 & 11.92 & 13.42 & 11.45 & 15. & 12.46 & 13.0211 .6018$. & 13.37 & 14.01 & 11.0112 .15 & 13.3915 .17 & 10.38 & 11.77 \\
\hline Hulling capacity, kg/h & 7.33 & 4.13 & 6.38 & 8.15 & 7.36 & 5.65 & 6.04 & 8.8 & 7.37 & $\begin{array}{lll}7.08 & 5.47 & 10.5\end{array}$ & 5.15 & 5.94 & $5.21 \quad 6.32$ & $5.23 \quad 4.62$ & 4.77 & 5.05 \\
\hline Capacity utilisation, $\%$ & 93.05 & 94.36 & 90.72 & 99.46 & 91.22 & 93.94 & 93.72 & 92.17 & 96.34 & 93.5296 .1090 .88 & 89.81 & 93.40 & 92.1588 .71 & 89.8193 .40 & 92.15 & 88.71 \\
\hline
\end{tabular}

F35, Faro 35; F44, Faro 44; F55, Faro 55.

Table 4. Average dimensions of studied parboiled paddy at $12.00-13.99 \%$ moisture content.

\begin{tabular}{lccccccccc} 
Variety & \multicolumn{2}{c}{ Faro 35 } & \multicolumn{2}{c}{ Faro 44 } & \multicolumn{3}{c}{ Faro 55 } & \multicolumn{2}{c}{ Ofada } \\
Tlype & Paddy & Dehulled & Paddy & Dehulled & Paddy & Dehulled & Paddy & Dehulled \\
Length (L) (mm) & 8.78 & 6.20 & 8.90 & 6.79 & 8.12 & 6.31 & 7.13 & 5.44 \\
Width (W) (mm) & 2.60 & 2.19 & 2.20 & 2.12 & 2.35 & 2.22 & 3.37 & 2.38 \\
\hline Thickness (mm) & 2.22 & 1.84 & 1.81 & 1.43 & 1.91 & 1.58 & 1.89 & 1.59 \\
L/W ratio & 3.34 & 2.83 & 4.05 & 3.20 & 3.46 & 2.84 & 2.12 & 2.29 \\
\hline Shape & - & Medium & - & Slender & - & Medium & - & Medium \\
Length classification & - & Medium & - & Long & - & Medium & - & Short \\
\hline
\end{tabular}


as reported by Dauda et al. (2012), which was highly affected by vibration as well as coefficient of dehulling of paddy.

Faro 55 and Ofada had maximum output capacity of 11.65 and 18.53 $\mathrm{kg} / \mathrm{h}$ respectively at MC $16.00-17.99 \%$ while Faro 35 and Faro 44 had maximum output capacity of 13.39 and $15.17 \mathrm{~kg} / \mathrm{h}$ respectively at 20.00 21.99\% MC as shown in Table 3. The varying results seen in output capacity agrees with Hunt (1977) that throughput is not always a constant base for comparison, as it varies with crop moisture conditions, and thus throughput ratings should be accompanied by a material moisture report.

Maximum average dehuller capacity utilisation was observed at various MC levels shown in Figure 4. Varying results of capacity utilisation (CU) for the varieties of paddy at different MC implies that CU depends on the rates of output as well as input, if the operation is not properly timed it could reduce or increase the machine capacity, this result agrees with what Dauda et al. (2011) reported. Table 5 is the statistical
"FARO 35 " FARO 44 " FARO 55 " OFADA

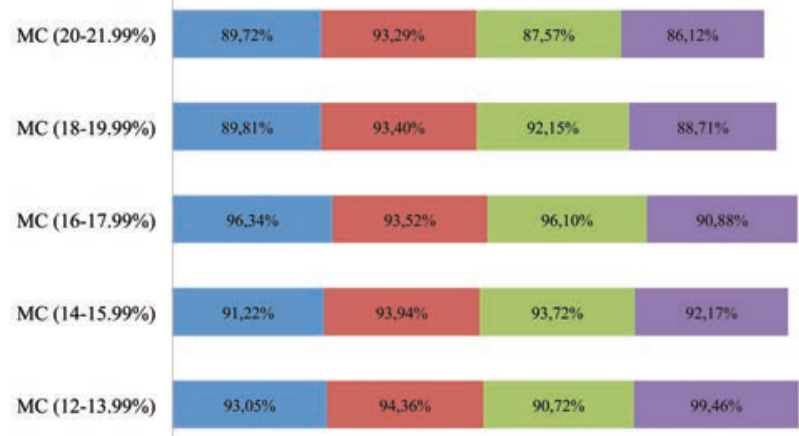

Figure 4. Effect of moisture content (MC) on capacity utilisation.

Table 5. Descriptive statistics of performance parameters (statistical difference of means).

\begin{tabular}{|c|c|c|c|c|c|c|c|}
\hline Variable & Test paddy & Total count & Mean & SE mean & St.Dev. & Minimum & Maximum \\
\hline Operating time & $\begin{array}{l}\text { F35 } \\
\text { F44 } \\
\text { F55 } \\
\text { Ofada }\end{array}$ & $\begin{array}{l}5 \\
5 \\
5 \\
5\end{array}$ & $\begin{array}{l}2.2100 \\
2.0290 \\
2.4800 \\
1.9230\end{array}$ & $\begin{array}{l}0.0829 \\
0.0529 \\
0.0196 \\
0.1410\end{array}$ & $\begin{array}{l}0.1853 \\
0.1182 \\
0.0437 \\
0.3150\end{array}$ & $\begin{array}{l}2.0100 \\
1.8450 \\
2.4200 \\
1.4650\end{array}$ & $\begin{array}{l}2.4100 \\
2.1550 \\
2.5300 \\
2.1950\end{array}$ \\
\hline Head rice, $\%$ & $\begin{array}{c}\text { F35 } \\
\text { F44 } \\
\text { F55 } \\
\text { Ofada }\end{array}$ & $\begin{array}{l}5 \\
5 \\
5 \\
5\end{array}$ & $\begin{array}{l}67.51 \\
50.58 \\
61.70 \\
69.33 \\
\end{array}$ & $\begin{array}{l}4.93 \\
4.79 \\
5.58 \\
5.83\end{array}$ & $\begin{array}{l}11.02 \\
10.71 \\
12.47 \\
13.03\end{array}$ & $\begin{array}{l}53.79 \\
36.95 \\
44.28 \\
52.49\end{array}$ & $\begin{array}{l}84.56 \\
65.58 \\
75.74 \\
84.51\end{array}$ \\
\hline Broken rice, $\%$ & $\begin{array}{c}\text { F35 } \\
\text { F44 } \\
\text { F55 } \\
\text { Ofada }\end{array}$ & $\begin{array}{l}5 \\
5 \\
5 \\
5\end{array}$ & $\begin{array}{l}32.49 \\
49.42 \\
38.30 \\
30.67\end{array}$ & $\begin{array}{l}4.93 \\
4.79 \\
5.58 \\
5.83\end{array}$ & $\begin{array}{l}11.02 \\
10.71 \\
12.47 \\
13.03\end{array}$ & $\begin{array}{l}15.44 \\
34.42 \\
24.26 \\
15.49\end{array}$ & $\begin{array}{l}46.21 \\
63.05 \\
55.72 \\
47.51\end{array}$ \\
\hline Coefficient of hulling & $\begin{array}{l}\text { F35 } \\
\text { F44 } \\
\text { F55 } \\
\text { Ofada }\end{array}$ & $\begin{array}{l}5 \\
5 \\
5 \\
5\end{array}$ & $\begin{array}{l}0.5237 \\
0.3983 \\
0.4999 \\
0.5259\end{array}$ & $\begin{array}{l}0.0559 \\
0.0453 \\
0.0205 \\
0.0256\end{array}$ & $\begin{array}{l}0.1250 \\
0.1014 \\
0.0459 \\
0.0573\end{array}$ & $\begin{array}{l}0.3851 \\
0.2983 \\
0.4594 \\
0.4289\end{array}$ & $\begin{array}{l}0.6331 \\
0.5437 \\
0.5674 \\
0.5691\end{array}$ \\
\hline Coefficient of wholeness & $\begin{array}{c}\text { F35 } \\
\text { F44 } \\
\text { F55 } \\
\text { Ofada }\end{array}$ & $\begin{array}{l}5 \\
5 \\
5 \\
5\end{array}$ & $\begin{array}{l}0.6825 \\
0.5139 \\
0.6132 \\
0.6938\end{array}$ & $\begin{array}{l}0.0506 \\
0.0520 \\
0.0549 \\
0.0579\end{array}$ & $\begin{array}{l}0.1133 \\
0.1162 \\
0.1227 \\
0.1294\end{array}$ & $\begin{array}{l}0.5392 \\
0.3773 \\
0.4439 \\
0.5265\end{array}$ & $\begin{array}{l}0.8543 \\
0.6701 \\
0.7523 \\
0.8444\end{array}$ \\
\hline Hulling efficiency & $\begin{array}{c}\text { F35 } \\
\text { F44 } \\
\text { F55 } \\
\text { Ofada }\end{array}$ & $\begin{array}{l}5 \\
5 \\
5 \\
5\end{array}$ & $\begin{array}{l}35.80 \\
20.36 \\
31.05 \\
36.98\end{array}$ & $\begin{array}{l}4.89 \\
2.70 \\
3.95 \\
4.42 \\
\end{array}$ & $\begin{array}{l}10.94 \\
6.04 \\
8.84 \\
9.88 \\
\end{array}$ & $\begin{array}{l}25.45 \\
11.49 \\
20.39 \\
22.58 \\
\end{array}$ & $\begin{array}{l}50.54 \\
27.14 \\
42.69 \\
46.56\end{array}$ \\
\hline Dehulling recovery & $\begin{array}{c}\text { F35 } \\
\text { F44 } \\
\text { F55 } \\
\text { Ofada }\end{array}$ & $\begin{array}{l}5 \\
5 \\
5 \\
5\end{array}$ & $\begin{array}{l}46.12 \\
32.91 \\
42.63 \\
46.90\end{array}$ & $\begin{array}{l}6.87 \\
4.71 \\
2.48 \\
3.25\end{array}$ & $\begin{array}{l}15.37 \\
10.53 \\
5.55 \\
7.26\end{array}$ & $\begin{array}{l}29.49 \\
20.30 \\
36.19 \\
34.79\end{array}$ & $\begin{array}{l}61.22 \\
47.81 \\
50.19 \\
51.73\end{array}$ \\
\hline Cleaning efficiency & $\begin{array}{c}\text { F35 } \\
\text { F44 } \\
\text { F55 } \\
\text { Ofada }\end{array}$ & $\begin{array}{l}5 \\
5 \\
5 \\
5\end{array}$ & $\begin{array}{c}88.93 \\
89.57 \\
87.216 \\
89.433\end{array}$ & $\begin{array}{c}1.59 \\
1.48 \\
0.973 \\
0.805\end{array}$ & $\begin{array}{c}3.56 \\
3.31 \\
2.175 \\
1.800\end{array}$ & $\begin{array}{c}85.90 \\
87.26 \\
84.721 \\
87.588\end{array}$ & $\begin{array}{l}94.60 \\
94.73 \\
90.66 \\
91.85\end{array}$ \\
\hline Output capacity & $\begin{array}{c}\text { F35 } \\
\text { F44 } \\
\text { F55 } \\
\text { Ofada }\end{array}$ & $\begin{array}{l}5 \\
5 \\
5 \\
5\end{array}$ & $\begin{array}{l}12.544 \\
13.892 \\
11.140 \\
14.390\end{array}$ & $\begin{array}{l}0.369 \\
0.363 \\
0.213 \\
1.080\end{array}$ & $\begin{array}{l}0.825 \\
0.811 \\
0.477 \\
2.410\end{array}$ & $\begin{array}{l}11.583 \\
13.019 \\
10.384 \\
11.770\end{array}$ & $\begin{array}{l}13.391 \\
15.168 \\
11.602 \\
17.380\end{array}$ \\
\hline Hulling capacity & $\begin{array}{c}\text { F35 } \\
\text { F44 } \\
\text { F55 } \\
\text { Ofada }\end{array}$ & $\begin{array}{l}5 \\
5 \\
5 \\
5\end{array}$ & $\begin{array}{l}6.487 \\
5.483 \\
5.576 \\
7.659\end{array}$ & $\begin{array}{l}0.530 \\
0.518 \\
0.288 \\
0.876\end{array}$ & $\begin{array}{l}1.186 \\
1.158 \\
0.643 \\
1.959\end{array}$ & $\begin{array}{l}5.149 \\
4.129 \\
4.770 \\
5.048\end{array}$ & $\begin{array}{l}7.369 \\
7.078 \\
6.381 \\
9.891\end{array}$ \\
\hline Capacity utilisation & $\begin{array}{c}\text { F35 } \\
\text { F44 } \\
\text { F55 } \\
\text { Ofada } \\
\end{array}$ & $\begin{array}{l}5 \\
5 \\
5 \\
5\end{array}$ & $\begin{array}{l}92.030 \\
93.700 \\
92.050 \\
90.270\end{array}$ & $\begin{array}{l}1.240 \\
0.197 \\
1.430 \\
2.620 \\
\end{array}$ & $\begin{array}{l}2.760 \\
0.442 \\
3.200 \\
5.850\end{array}$ & $\begin{array}{l}89.720 \\
93.286 \\
87.570 \\
84.880 \\
\end{array}$ & $\begin{array}{l}96.34 \\
94.36 \\
96.10 \\
99.46 \\
\end{array}$ \\
\hline
\end{tabular}

SE, standard error; St.Dev., standard deviation; F35, Faro 35; F44, Faro 44; F55, Faro 55. 
Table 6. Prototype huller performance at critical operating parameters.

\begin{tabular}{lc}
\hline Performance parameters & Maximum values \\
Coefficient of dehulling & 0.63 \\
Coefficient of wholeness & 0.85 \\
\hline Dehulling efficiency, \% & 50.54 \\
Dehulling recovery, \% & 61.22 \\
\hline Cleaning efficiency, \% & 94.73 \\
Input capacity, $\mathrm{kg} / \mathrm{h}$ & 20.41 \\
\hline Output capacity, $\mathrm{kg} / \mathrm{h}$ & 18.53 \\
Hulling capacity, $\mathrm{kg} / \mathrm{h}$ & 10.56 \\
\hline Capacity utilisation, $\%$ & 99.46 \\
\hline
\end{tabular}

summary of the tested machine performance parameters showing the means, the differences on various rice varieties, the standard deviations, minimum and maximum values.

Table 6 shows the prototype huller performance at optimum operating settings of metering, roller speeds and blow speed settings. The testing result after improvement on the machine stability gave coefficient of dehulling as 0.82 , dehulling efficiency was $65 \%$ and dehulling recovery was $75 \%$.

\section{Conclusions}

Results showed the optimum MC for Ofada, Faro 55, and Faro 44 and Faro 35 and cleaning efficiency (grain purity), coefficient of dehulling, coefficient of wholeness, dehulling efficiency, dehulling recovery, input capacity, output capacity, dehulling capacity, and capacity utilisation obtained was found to be optimum at $94.60 \%, 0.63,0.85,50.54 \%$, $61.22 \%, 20.41 \mathrm{~kg} / \mathrm{h}, 18.53 \mathrm{~kg} / \mathrm{h}, 10.56 \mathrm{~kg} / \mathrm{h}, 99.46 \%$ respectively. After improvement on the machine, coefficient of dehulling was 0.82 , dehulling efficiency was $65 \%$ and dehulling recovery was $75 \%$. The coefficient of wholeness increased as breakage decreased while long and slender grains had more breakage than shorter grains indicating the effect of physical shape of the paddy varieties. The prototype dehuller was effective for its intended function; however the coefficient of dehulling ( 0.63$)$ could be improved with better roller material and quicker means of machine settings.

\section{References}

Adewunmi J.K., Olayanju T.M.A., Adewuyi S.A. 2007. Support for small rice threshers in Nigeria. PrOpCom monograph series \#23. Department for International Development (DFID)/PrOpCom project, Abuja, Nigeria. Available from: http://www.propcommaikarfi. org/wp-content/uploads/2013/08/23-Support-for-small-rice-threshers-in-Nigeria-8-07.pdf
Dauda S.M., Adeoye P.A., Bello K., Agboola A.A. 2012. Performance evaluation of a locally developed rice dehulling machine. Int. J. Agron. Agr. Res. 2:15-21.

Dilday R.H. 1987. Influence of thresher cylinder speed and grain moisture at harvest on milling yield of rice. Arkansas Acad. Sci. 41:35-7.

Firouzi S., Alizadeh M.R., Minaei S. 2010. Effect of rollers differential speed and paddy moisture content on performance of rubber roll husker. Int. J. Agr. Biol. Sci. 1:1.

Goodman D., Rao R. 1985. Effect of grain type and milled rice kernel hardness on the head rice yield. J. Food Sci. 50:840.

Hwang S.H., Barsa R., Tan C. 2005. The facts about Teflon. Available from: http://teflonfacts.blogspot.it

Hunt D.R. 1977. Farm Power and machinery management. Iowa State University Press, Ames, Iowa.

IRRI (International Rice Research Institute). 1996. Standard evaluation systems for rice. 4th ed. INGER Genetic Resources Centre. IRRI, Manila, Philippines.

IRRI (International Rice Research Institute). 2009a. Measuring quality of paddy. Rice knowledge bank. Available from: http://www.knowledgebank.irri.org

IRRI (International Rice Research Institute). 2009b. Rubber roll husker, rice knowledge bank. Available from: http://www.knowledgebank.irri.org

Ituen E.U.U, Ukpaka A.C. 2011. Improved method of par-boiling paddy for better quality rice. World J. Appl. Sci. Technol. 3:31-40.

Matthews J., Abadie T. J., Deobald H. J., Freeman C.C. 1970. Relation between head rice yields and defective kernels in rough rice. Rice J. 73:6-12.

Mejia D.J. 2003. An overview of rice post-harvest technology: use of small metallicsilos for minimizing losses. Proc. 20th Session of the International Rice Commission, July 23-26 2002, Bangkok, Thailand.

NCRI (National Cereals Research Institute), WARDA (Africa Rice Centre). 2007. Definition of Ofada rice qualities through varietal identification and testing. PrOpCom monograph series \#26. Department for International Development (DFID)/PrOpCom project, Abuja, Nigeria. Available from: http:/www. propcommaikarfi. org/wp-content/uploads/2013/08/26-Definition-of-Ofada-Rice-qualities-through-varietal-identification-ans-testing-8-071.pdf

Ogunforowa 0.2007. Financial analysis of parboiling and milling techniques in the Kura Kano Corridor. PrOpCom monograph series \#18. Department for International Development (DFID)/PrOpCom project, Abuja, Nigeria. Available from: http://www.propcommaikarfi.org/wp-content/uploads/2013/08/18-Financial-Analysis-ofParboiling-and-Milling-Techniques-in-the-Kura-Kano-Corridor-3071.pdf

Payman M., Bagheri I., Alizadeh M.R., Roohi R. 2006. Effective parameters of broken rice during paddy hulling using rubber roll huller. J. Biol. Sci. 7:47-51.

PNS (Philippine National Standard), PAES (Philippine Agricultural Engineering Standard). 2004. PNS/PAES 214:2004. Agricultural machinery rubber roll for rice mill - methods of test. Available from: https://law.resource.org/pub/ph/ibr/pns.214.2005.pdf 